\title{
ІНТОНАЦІЙНО МАРКОВАНІ ФРАЗЕОЛОГІЗОВАНІ РЕЧЕННЯ: СТАТУС ТА ОЗНАКИ
}

Ситар Г. В. Інтонаційно марковані фразеологізовані речення: статус та ознаки.

Статтю присвячено розгляду речень, які можуть виступати як фразеологізовані і як нефразеологізовані залежно від інтонації, реалізованої в певній ситуації та в певному контексті. Визначено місце інтонаційно маркованих фразеологізованих речень у системі фразеологічних одиниць; з'ясовано їхні диференційні ознаки; виділено чинники, які мотивують можливість виникнення особливого типу синтаксичної омонімії - омонімії фразеологізованих і нефразеологізованих речень в українській мові.

Ключові слова: інтонація, синтаксичний фразеологізм, фразеологізоване речення, фразеологічна одиниця, українська мова.

Ситарь А. В. Интонационно маркированные фразеологизированные предложения: статус и признаки.

Статья посвящена рассмотрению предложений, которые могут выступать как фразеологизированные и как нефразеологизированные в зависимости от интонации, реализованной в определенной ситуации и в определенном контексте. Установлено место интонационно маркированных фразеологизированных предложений в системе фразеологических единиц; определены их дифференционные признаки; выделены факторы, мотивирующие возможность возникновения особенного типа 
синтаксической омонимии - омонимии фразеологизированных и нефразеологизированных предложений в украинском языке.

Ключевые слова: интонация, синтаксический фразеологизм, фразеологизированное предложение, фразеологическая единица, украинский язык.

Sytar H. V. Intonationally Marked Sentences with Phraseological Structures: Status and Features.

The article is devoted to consideration of sentences that can act as both sentences with phraseological structures and regular ones, depending on the intonation carried out in a particular situation and context. The place of intonationally marked sentences with phraseological structures in the system of phraseological units was determined; their differential features were revealed; there were identified the factors that motivate the potential of initiation of a special type of syntactic homonymy - homonymy of sentences with phraseological structures and regular ones in Ukrainian.

Key words: intonation, syntactic idiom, sentence with phraseological structure, phraseological unit, the Ukrainian language.

Фразеологічний фонд кожної мови як відбиття національно-мовних особливостей певного народу цілком закономірно привертає увагу мовознавців. Попри наявність значної кількості досліджень, численні питання, пов'язані зі статусом, ознаками, межами та типами фразеологічних одиниць, на сьогодні залишаються остаточно не розв'язаними.

Одним із найменш досліджених аспектів фразеології є інтонаційне оформлення фразеологічних одиниць, з'ясування ролі інтонації в їхньому формуванні. Така невивченість зумовлена кількома причинами. По-перше, традиційно фразеологізми досліджують переважно на матеріалі писемних джерел, залучають відомості фразеологічних словників. Оскільки в письмових текстах інтонаційні властивості фразеологізмів експліцитно не втілені, вони залишаються поза увагою дослідників [10, с. 243]. По-друге, 3'ясування особливостей інтонаційного оформлення фразеологічних одиниць в усному мовленні неминуче ставить питання про коректні методи їхнього аналізу, якими $є$ комп'ютерні програми 3 автоматичного оброблення мовлення, які дають змогу отримати та зіставити інтонограми відповідних мовленнєвих одиниць. У розрізі цього дослідження особливостей організації інтонаційно маркованих фразеологізованих речень (обгрунтування цього поняття див. нижче) в українській мові $\epsilon$ актуальним та ще не розв'язаним завданням сучасних лінгвістичних студій, що перебувають на перетині фразеології, синтаксису та інтонології.

Окремі зауваги щодо ролі інтонації у процесі фразеологізації висловлювали ще в середині ХX ст. Л. Ройзензон, І. Федосов, М. Копиленко, 3. Попова [3, с. $86 ; 11$, с. 206-209; 14, с. 25] та інші 
лінгвісти. Зокрема, Л. Ройзензон за роллю інтонації у межах фразеологізмів розмежував дві групи - інтонаційно марковані та інтонаційно немарковані фразеологічні одиниці [11, с. 206-209].

У працях останніх років $є$ спроби виділити окремий клас фразеологічних одиниць, у формуванні яких інтонація відіграє вирішальну роль $[12 ; 10 ; 1 ; 4 ; 15 ; 16]$. Ідеться про висловлення на зразок Добра порада! Дуже треба! Що за день! (Що за день?), які можуть вимовлятися з різною інтонацією і відповідно передавати різний зміст, різну оцінку мовцем реалії або ситуації загалом, реалізовувати різну комунікативну настанову. У писемних текстах трактування змісту подібних речень відбувається з урахуванням контексту:

Хвилини терпкого вичікування, потім:

- Eŭ, хто там?

- Свої.

- Що залюди?

- 3 окопів люди. А ви? Ви-намі?

- Hami (О. Гончар. Людина і зброя) (питальне нефразеологізоване речення);

А резолючію яку тоді ухвалили: «Незважаючи на те, що в нас залишились каліки, діди та баби, ворогам револючії не ходити на нашій землі. Озброїмось косами, вилами, мітлами $і$ зметемо їх з лиця землі. Висловлюємо повну готовність стояти до останньої краплі крові за Ради робітничих, солдатських $і$ селянських депутатів». I як стоять! Ex, тимофію, що за люди це! (М. Стельмах. Велика рідня) (фразеологізоване речення зі значенням позитивної оцінки);

...Коли він вперше пробіг по коридору і вскочив у цех друкарні у цих неймовірних джинсах $і$ вишитій сорочці, дівчата підняли веселий твалт, а Микола Сергійович, наче нічого не сталося, бурчав:

- Що за люди, наче штанів не бачили. Надалі Солодченко вже не виходив із кабінету, ховаючи ноги під письмовим столом. Але всі до нього забігали, начебто у справах, заглядали під стіл, а він хвицав ногами (О. Іванов. Штани) (фразеологізоване речення зі значенням негативної оцінки).

В україністиці питання про взаємозв'язок фразеологізації та інтонаційного оформлення конструкцій досі залишається не розв'язаним.

Мета пропонованого дослідження - з'ясувати статус речень на зразок Добра дівчина! Який розумний! Що за день! Щоб я з ним пращювала!, які можуть виступати як фразеологізовані і як нефразеологізовані залежно від інтонації, реалізованої в певній ситуації та в певному контексті. Поставлена 
мета передбачає розв'язання таких завдань: 1) проаналізувати погляди вчених на інтонаційно марковані речення; 2) визначити статус інтонаційно маркованих фразеологізованих речень у системі фразеологічних одиниць; 3) з'ясувати їхні диференційні ознаки; 4) виділити чинники, які мотивують можливість виникнення особливого типу синтаксичної омонімії - омонімії фразеологізованих і нефразеологізованих речень.

Термін «інтонаційний фразеологізм» на позначення специфічного типу фразеологічних одиниць увела до наукового обігу відомий фонетист Н. Свєтозарова [16; 12 та ін.]. Її учениця М. Архипецька кваліфікує інтонаційні фразеологізми як «особливі фразеологічні одиниці розмовного мовлення, комунікативне значення яких, не виражене експліцитно (лексично), визначається виключно за їхніми інтонаційними характеристиками» [1, c. 4]. Підтримує виділення інтонаційних фразеологізмів як окремого типу фразеологічних одиниць ще одна представниця Санкт-Петербурзької школи А. Павлова. Дослідниця визначає інтонаційні фразеологізми та фразеосхеми (термін Д. Шмельова, у нашій термінології - фразеологізовані речення, або синтаксичні фразеологізми) як «білі плями» сучасної фразеології [10].

I. Логінова вважає термін «інтонаційний фразеологізм» дискусійним на підставі некоректності кваліфікації інтонації як основної відмінності вільних сполучень слів та фразеологічних одиниць, оскільки інтонаційне оформлення останніх «є варіативним і залежить від контексту та емоційного стану мовця» [9, с. 218]. Дослідниця наголошує на існуванні сукупності диференційних ознак фразеологізмів, а експресивні значення висловлень на зразок Яка в нього машина! Як вона cniвaє! тлумачить як «регулярні властивості самих ІК (інтонаційних конструкцій)» $[9, \quad$ с. 220]. Попри сформульоване I. Логіновою протиставлення поглядів, зазначені підходи не суперечать один одному, оскільки: 1) інтонаційне оформлення Н. Свєтозарова, М. Архипецька та А. Павлова вважають важливим параметром фразеологізмів загалом, водночас його розглядають як вирішальний чинник формування не всіх фразеологічних одиниць, а тільки тих, що мають відповідні омоніми вільні речення; 2) інтонацію дослідниці також розглядають не окремо, а в межах комплексу ознак фразеологізмів, пор.: «Інтонація грає виключно важливу роль у фразеології, поряд 3 ідіоматичністю (семантичними зсувами у значеннях слів ідіом), цільнооформленістю, нерозчленованістю, стійкістю, відтворюваністю. Імовірно, немає смислу визначати, яке місце за ступенем важливості в цьому списку належить інтонації, однак вона має всі підстави в цьому списку фігурувати: без неї (ㄷ Г. В. Ситар, 2015. 
він не є повним. А у сфері так званих інтонаційних фразеологізмів, або інтонаційних кліше, або фразових вигуків (термінів для позначення цього явища кілька) інтонація грає відверто провідну роль» [10, с. 243]; 3) за інтонаційним контуром (інтонаційною конструкцією) визнають право передавати певне значення: «...інтонаційним фразеологізмом можна вважати не тільки конкретну лексико-граматичну структуру, але й власне інтонаційний контур, що передає певне емоційне значення» [1, с. 17].

У межах неоднослівних інтонаційних фразеологізмів М. Архипецька виділяе дві групи за типом лексико-граматичного наповнення: 1) інтонаційні фразеологізми закритої структури, які не дозволяють лексичних змін, заповнення / незаповнення факультативних або введення додаткових компонентів: рос. Всю жизнь мечтал! Еще чего!; 2) інтонаційні фразеологізми відкритої структури, які відповідають фразеологізованим реченням у нашому розумінні: рос. Тоже (мне) [врач] нашелся! Куда/где (уж) ему! [1, с. 18] (у наведених прикладах збережено запис М. Архипецької).

Спираючись на погляди Л. Ройзензона [11, с. 206-209], Н. Курникова обгрунтовує доцільність терміна «інтонаційно марковані фразеологічні одиниці» (далі ІМФО), до складу яких зараховує не тільки фразеологізовані речення, які $є$ предметом нашого дослідження, але й окремі лексичні (традиційні) фразеологізми, які мають омонімічні вільні речення, а також вигукові фразеологізми [4]. Широкий підхід до розуміння інтонації та здійснений на його підставі аналіз мелодичного малюнку, темпу, тембру, пауз та наголосу ІМФО дає змогу дослідниці виділити регулярні для ІМФО інтонаційні конструкції (далі ІК) - IК-5, ІК6 та ІК-7 (типи ІК подано за авторитетною класифікацією О. Бризгунової) - та дійти до висновку, що інтонаційне оформлення таких одиниць становить «один з найскладніших видів інтонації у фразеології, оскільки саме у фразеологічних одиницях цієї групи відбувається суміщення трьох функцій інтонації: фонетично організувальної, засобу фразеологізації, смислорозрізнювальної» [4, с. 17]. Термін «інтонаційно марковані фразеологічні одиниці» видається коректним, оскільки акцентує на центральній ролі інтонації у формуванні зв'язаного значення відповідних одиниць та передбачає протиставлення 3 іншими фразеологічними одиницями, які, безумовно, також мають певне інтонаційне оформлення, але воно не мотивує виникнення зв'язаного значення.

Цікаво, що на специфічний випадок омонімії речень звертають увагу саме вчені-інтонологи, водночас, на нашу думку, такі одиниці мають розглядатися і з власне-синтаксичних позицій і кваліфікуватися як 
один із типів синтаксичної омонімії, оскільки йдеться про омонімію вільних і фразеологізованих висловлень, тотожних за структурою та лексичним наповненням, але відмінних інтонаційно.

3-поміж спеціальних праць, присвячених синтаксичній фразеології (або синтаксичній ідіоматиці), варто відзначити дослідження М. Всеволодової та Йон Лім Су, у яких не тільки заакцентовано потребу встановлення взаємозв'язків синтаксису та інтонації, виділено смислорозрізнювальну функцію інтонації для вільних та фразеологізованих речень 3 тотожним компонентним складом, але й здійснено спробу інтонаційного аналізу оцінних синтаксичних фразеологізмів як одного з найбільших класів одиниць цього типу на матеріалі російської та корейської мов [2; 5 та ін.]. Спираючись на типологію ІК російської мови О. Бризгунової, дослідниці виділили типові для цього класу синтаксичних фразеологізмів IК - IК-2, IК-5, IК-3 та ІК-7.

Статус фразеологізованих речень загалом визначено у працях [2; 6; 7; 8; 13 та ін.]. У межах широкого підходу до фразеологічних одиниць дослідники зазначають, що процес фразеологізації відбувається в межах різних мовних одиниць. Результатом фразеологізації речення як предикативної синтаксичної одиниці $\epsilon$ утворення окремого типу фразеологічних одиниць - синтаксичних фразеологізмів, або фразеологізованих речень. Спільними ознаками лексичних (традиційних) та синтаксичних фразеологізмів $є$ неоднослівність, стійкість, цілісність значення, неможливість вивести його із суми значень компонентів, що утворюють фразеологічну одиницю, та ескпресивність; відмінності ж стосуються типу мовної одиниці, у межах якої відбувається фразеологізація; відтворюваності / невідтворюваності, призначення, низки структурних, лексичних і граматичних параметрів; чинників, які беруть участь у формуванні зв'язаного значення, та характеру еквівалентних мовних одиниць (докладно див. [13]).

3-поміж усього загалу фразеологізованих речень виділяємо два типи речень за наявністю/відсутністю висловлень-омонімів та виконанням / невиконанням інтонацією смислорозрізнювальної функції.

1. Фразеологізовані речення, які мають відповідник - омонімічне нефразеологізоване речення, смислорозрізнювальну функцію в такому разі виконує саме інтонація: Яка дівчина! та Яка дівчина?; Скільки нас на планеті? та Скільки нас на планеті!; Добрий вчинок! і т. ін. На позначення речень цього типу коректним вважаємо термін «інтонаційно марковані фразеологізовані речення».

2. Фразеологізовані речення, які не мають вільних речень-омонімів (ㄷ Г. В. Ситар, 2015. 
(принаймні на сучасному етапі розвитку мови): Оие так зустріч! Чим не подарунок! Дівчина як дівчина. Закон є закон та ін.

Одиниці першого типу А. Павлова цілком слушно трактує як площину перетину фразеологізованих речень (фразеосхем) та інтонаційних фразеологізмів: «Фразеосхеми та інтонаційні фразеологізми - множини, що перетинаються. <...> Описати підмножину перетину, тобто фразеосхеми, які водночас $\epsilon$ інтонаційними фразеологізмами, - ще одне 3 цікавих i досі нерозв'язаних завдань фразеології та інтонології» [10, с. 245-246].

М. Архипецька зазначає, що інтонаційні фразеологізми «можуть мати лексико-граматичні омоніми (далі ЛГО), тобто висловлення 3 ідентичним лексико-граматичним складом, але іншим комунікативним призначенням» $[1$, с. 4]. Виокремлення семантичних та просодичних відмінностей інтонаційних фразеологізмів стає можливим саме завдяки зіставленню з ЛГО, пор. російські речення Будет он работать (вільне розповідне речення), Будет он работать? (вільне питальне речення) та Будет он работать! (інтонаційний фразеологізм із заперечним значенням) [1, с. 4-5].

М. Архипецька виділяє такі диференційні ознаки інтонаційних фразеологізмів, як надслівність, особливий спосіб номінації (узагальненоцілісне значення), стійкість, відтворюваність, загальновідомість, експресивність, мовна специфіка (неперекладність), побутово-розмовний характер та першорядна значущість інтонаційних засобів у формуванні комунікативного значення [1, с. 4; 14-18]. При цьому перші вісім критеріїв дають змогу зарахувати їх до класу фразеологічних одиниць, а останній - трактувати як особливий вид - інтонаційні фразеологізми.

3 усіх перерахованих параметрів інтонаційно маркованим фразеологізованим реченням невластиві відтворюваність та особливий спосіб номінації, оскільки фразеологізовані речення не відтворюються, а будуються мовцем у більш чи менш готовому вигляді, їх основним призначенням $є$ не номінація, а вираження суб'єктивно-модальних значень - оцінки, згоди, заперечення, необхідності, неможливості та ін. [13]. Відносними також є загальновідомість та неперекладність, оскільки правильне використання таких моделей речень потребує глибоких знань синтаксису та навичок спілкування певною мовою, водночас еквівалентні моделі речень $€$ в багатьох мовах світу.

Аналіз зібраного фактичного матеріалу дає змогу виділити деякі параметри, характерні для інтонаційно маркованих фразеологізованих i нефразеологізованих речень-омонімів.

1. Наявність оцінної лексики (в іменних моделях оцінка передається 
за допомогою атрибутивних поширювачів типу добрий, иікавий, у дієслівних - адвербіальних компонентів типу вдало, добре, чудово):

Олеся догадалась, щчо Балабуха усе бачив з гори з-за кущів; ї̈ взяла злість.

- А хоч би й жаби печерувала! Що ж у тому поганого? Покарав мене господь тобою: вмієш за кущами підстерігати, а за возами не підстерігаєш. Он твої вози порозпадались серед базару жидам на смішки. Добрий господар! Доведеться самій ходити коло возів (І. НечуйЛевицький. Старосвітські батюшки та матушки);

Знаю Богдана давно. Добрий господар, розумний керівник, хороший товариш. Таким людям треба давати дорогу у велику політику! (http://bug.org.ua/interview/46170-46170/).

2. Заповнення позиції змінного іменного компонента моделі речень абстрактними іменниками (диво, любов, новина і под.), які уможливлюють різну оцінку мовцем відповідної реалії:

Цілувала-пестила, аж губи припухли. Оие любов! (Л. Дашвар. Биті $\epsilon$. Макар) (фразеологізоване речення з позитивною оцінкою);

Оие, думаю, турбота про людей! I допомогу дали, $i$ ще й за здоров'я наших бджіл турбуються. Через кілька днів приношу я той бджолиний підмор у державну ветеринарну лабораторію, куди $і$ було сказано. А там мені - за аналізи з кожної бджолосім'ї плати більш як по двадиять гривень. Прикинув я: дали 120 гривень, а забирають більше 200... Оие любов!.. Не треба мені такої державної допомоги (http://tviybiznes.com/main/news2/164434) (фразеологізоване речення 3 негативною оцінкою).

3. Уведення до моделі речення факультативних компонентів часток, вигуків, які підсилюють та уточнюють оцінне значення:

Які люди! Які тільки дорогі люди проходили ичими східиями! Звідичіля пішов моряк у село $і$ відстрілювався від банди до останнього набою (Г. Тютюнник. Вир) (фразеологізоване речення з позитивною оцінкою);

Син. Не зліть мене, батьку, я в атаку йшов! Зрозуміли?

Батько. Тепер однаково, - в атаку, не в атаку. Війна кінчається.

Син. Це Бєлгородська дуга! Зрозумів? (Постукав по милиці).

Батько. Хай буде дуга. Тільки ти ї̈ поменш виставляй, щоб людям на тебе не було незручно дивитись.

Син. Тобто як ие так?

Батько. А так, щчо не обтяжуй людей. Людям і без твоєї дуги важко, синку.

Син. Ну, спасибі, тату! Он які люди!

(ㄷ Г. В. Ситар, 2015. 
Батько. Люди як люди. У кожного своя біда. Так щзо подякуй долі та й кульгай собі делікатно, не пияч, не горлай та утримуйся від брехень (О. Довженко. Повість полум'яних літ) (фразеологізоване речення 3 негативною оцінкою).

4. 3-поміж синтаксичних особливостей відзначимо випадки своєрідної парцеляції, за якої фразеологізоване речення за формою $є$ підрядною частиною складного речення, що вживається самостійно, без головної частини, унаслідок чого виникає фразеологізоване значення:

- Слухай, Тимоше, покинь мою розлучницю! покинь, коли не хочеш каятись вік! Буде каяння, та вороття не буде!

- Щоб я ї̈ покинув! Дурно тільки слова твої гинуть. Не зраджу своєї дівчини, поки жив буду, поки світ сонця! (Марко Вовчок. Чари) (фразеологізоване речення зі значенням заперечення дії), пор.:

Мій владарю! 3 якою недоброю промовою ти звернувся до мене тепер. Ти пропонуєш мені видати тобі жінку, від якої я маю синів, тепер уже дорослих юнаків, та дочок, із котрих одну ти взяв за жінку для твого сина, жінку, щзо ї̈ я люблю всім серцем, цџю жінку ти хочеш забрати від мене, щоб я ї̈ покинув $і$ щоб я одружився з твоєю дочкою? (Геродот. Історії в дев'яти книгах. Переклад А. Білецького) (нефразеологізоване речення, що є підрядною з'ясувальною частиною в межах складного речення).

5. Реалізація дієслівних речень без типових передбачуваних поширювачів (напр., поширювачів місця для дієслів руху), що поєднується з уведенням поширювачів з оцінним значенням, пор.:

Мені вже 11 місяиів, за ией місяџь я дуже багато навчилась. 3 розумового розвитку - я вмію робити баран-баран, показувати тосітосі, па-па і де в мами носик. Правда на замовлення показую рідко. 3 фізичного розвитку - добре ходжу біля опори, за дві ручки, стою пару секунд без опори, дуже активно повзаю по изілій хаті, встаю біля будьякої опори, деколи можу присісти не тримаючись (http://www.minibanda.ru/u/13694/note/11-msyacv-2-2) (вільне речення);

- Де ти ходиш, де ти бродиш? - почала гримати на чоловіка Кайдашиха: вона думала, що він пив до півночі в шинку.

- Еге, ходиш... Добре ходжу... Не сам ходжу, а мене водить, промовив Кайдаш через силу, схиливши голову на руку. - Завела мене нечиста сила аж у Богуславський ліс (І. Нечуй-Левицький. Кайдашева сім'я) (фразеологізоване речення зі значенням заперечення).

Отже, серед фразеологізованих речень виділяємо два типи речень $3 a$ наявністю / відсутністю висловлень-омонімів та виконанням / 
невиконанням інтонацією смислорозрізнювальної функції. На позначення речень першого типу вживаємо термін «інтонаційно марковані фразеологізовані речення».

Випадки вживання речень-висловлень, які залежно від інтонації в різному контексті та в різних ситуаціях можуть виступати як вільні і як фразеологізовані, вважаємо особливим різновидом синтаксичної омоніміі. Виняткову роль у встановленні статусу таких висловлень відіграє інтонація, яка у фразеологізованих реченнях виконує одночасно три функції - фонетично організувальну, засобу фразеологізації та смислорозрізнювальну. 3'ясування специфіки їхнього інтонаційного оформлення потребує залучення комп'ютерних програм 3 аналізу мовлення, що і $є$ перспективою наших подальших досліджень.

\section{Література}

1. Архипецкая М. В. Интонационные фразеологизмы со значением эмоционального отрицания : автореф. ... дисс. канд. филол. наук / М. В. Архипецкая. - СПб., 2012. - 26 c.

2. Всеволодова М. В. Принципы лингвистического описания синтаксических фразеологизмов : На материале синтаксических фразеологизмов со значением оценки / М. В. Всеволодова, Ён Лим Су. - М. : МАКС Пресс, 2002. - 164 с.

3. Копыленко М. М. Очерки по общей фразеологии / М. М. Копыленко, 3. Д. Попова. - Воронеж : Изд-во Воронежского ун-та, 1978. - 141 с.

4. Курникова Н. В. Интонационно маркированные фразеологические единицы в современном русском литературном языке : дисс. ... канд. филол. наук / Н. В. Курникова. - Иваново, 2003. - 206 с.

5. Лим С. Ё. Принципы лингвистического описания синтаксических фразеологизмов : на материале синтаксических фразеологизмов с общим значением оценки : автореф. дис. ... канд. филол. наук / Ё. С. Лим. - М., 2001. - 26 с.

6. Личук М. І. Ступені фразеологізації речень : автореф. дис. ... канд. філол. наук / М. І. Личук. - К., 2001. - 16 с.

7. Личук М. І. Ступені фразеологізації речень / М. І. Личук, В.Д.Шинкарук / Чернівецький національний ун-т ім. Юрія Федьковича. - Чернівці : Рута, 2001. - 136с.

8. Мельчук И. А. Русский язык в модели «Смысл $\Leftrightarrow$ Текст» / И. А. Мельчук. - М. - Вена : Школа «Языки русской культуры», 1995. - 682 с.

9. Логинова И. М. Фразеология и просодия / И. М. Логинова // Вестник Новгородского государственного ун-та. - 2014. - № 77. - С. 218-221.

10. Павлова А. В. »Белые пятна» фразеологии: интонационные фразеологизмы и фразеосхемы / А. В. Павлова // Высшее гуманитарное образование XXI века: проблемы и перспективы. Материалы Седьмой международной научно-практической конференции. - Самара : ПГСГА, 2012. - С. 240-246.

11. Ройзензон Л. И. Лекции по общей и русской фразеологии : [учебное пособие] / Л. И. Ройзензон. - Самарканд : СамГУ, 1973. - 223 с.

12. Светозарова Н. Д. Интонационная фразеология (перцептивный анализ 
интонационных клише и идиом русского языка)/Н. Д. Светозарова // Вопросы русского языкознания. - Вып. 11. Аспекты изучения звучащей речи. Сб. научн. статей к юбилею Е. А. Брызгуновой. - М. : Изд-во МГУ, 2004. - С. 175-178.

13. Ситар Г.В. Статус синтаксичних фразеологізмів у системі фразеологічних одиниць / Г. В.Ситар // Вісник Донецького національного університету. Серія Б. Гуманітарні науки. - Донецьк : ДонНУ, 2011. - № 2. - С. 66-74.

14. Федосов И. А. Функционально-стилистическая дифференциация русской фразеологии / И. А. Федосов. - Ростов н/Д. : Изд-во Ростов. ун-та, 1977. - 211 с.

15. Хосейни А. Способы имплицитного выражения отрицания в интонационных фразеологизмах / А. Хосейни, Ф. С. Ганбари-Эрди // Молодой ученый. - 2015. № 8. - C. 186-189.

16. Svetozarova Natalia. Locutions praséologiques intonatives / N. Svetozarova // Actes du XII Congrès International des Sciènces Phonétiques. - Aix-en-Provence. - 1991. Vol. 2. - P. 274-277.

Стаття надійшла до редакиії 09.08.2015 p. 